\title{
THE METHODOLOGY OF EVOLUTIONARY AND NEOCLASSICAL ECONOMICS AS A CONSEQUENCE OF THE CHANGES IN THE CONCEPT OF HUMAN NATURE
}

The concept of human nature builds the basis for thinking about economics and its fundamental elements such as methodology, methods and crucial theories. Therefore, changes in the concept of human nature lead to changes in the fundamentals of economics. The goal of the paper is to present this impact using the example of evolutionary and neoclassical economics. The method applied to this research is, among others, a content analysis of the selected texts developed within neoclassical and evolutionary economics and the research undertaken about them. The analysis proves that the main differences between these economic schools might be explained by the diverse assumptions about human nature.

Keywords: methodology of economics, concept of human nature, neoclassical economics, evolutionary economics

JEL Classifications: B52, Z13, A12

DOI: $10.15611 /$ aoe.2017.2.06

\section{INTRODUCTION}

The main idea of the paper is that the concept of human nature influences the foundations of economics. The goal of the paper is to investigate the connections between the concept of human nature (in economic theories) and the fundamentals of economics. Neoclassical and evolutionary economics are taken as an example, because these two schools of economic thought are extremely different in their general assumptions about human nature.

The analysis of the concept of human nature and its potential impact ${ }^{1}$ on the foundations of economics relates to the basic dimensions and levels of the concept of human nature. It is oriented using the model described by Horodecka $(2002,2014 b)$, based on the philosophical ${ }^{2}$ and current

\footnotetext{
* Collegium of Economic Analysis, Warsaw School of Economics.

${ }^{1}$ The relations could potentially be inverse, but as concepts of human nature are understood as cognitive structures that precondition the epistemological process, we can speak of the impact of concepts of human nature on the foundations of economics and not the reverse.

${ }^{2}$ Among others such classic works as those of Plato, Aristotle and more recently, Frankl; see Aristotle and Everson (1988); Frankl (1997); Platon and Regner (2004).
} 
anthropological literature such as Thies (2004), Kamiński (2005), Krąpiec (2005), Rolle (2005) and Fahrenberg (2014). The basic dimensions refer to the worldview, ${ }^{3}$ the social world ${ }^{4}$ and the individual dimension, which can be analysed on three fundamental anthropological levels. The first 'body' level refers to human behaviour and can be described using objective methods. However, to understand this behaviour we need to know the motives responsible for it, which are thematized at the second level. The second 'soul' level (Greek 'psyche') provides an insight into the world of emotions, motives and experiences and can be explored using an intersubjective method. The third 'mind' level reports the structure and hierarchy of these motives which is possible on the meta-level of the individual. This level, which refers to reason and in this sense is usually oriented towards some ethical principles, norms or values - for instance justice, love, service - can be approached intersubjectively. Human nature, which manifests itself among others in decisions followed by intended actions, depends on two upper-level emotions/motives and/or reasons. ${ }^{5}$ Figure 1 presents the basic dimensions and levels of the concept of human nature, and the following table focuses on explaining the basic levels that we encounter within the individual dimension of the concept of human nature.

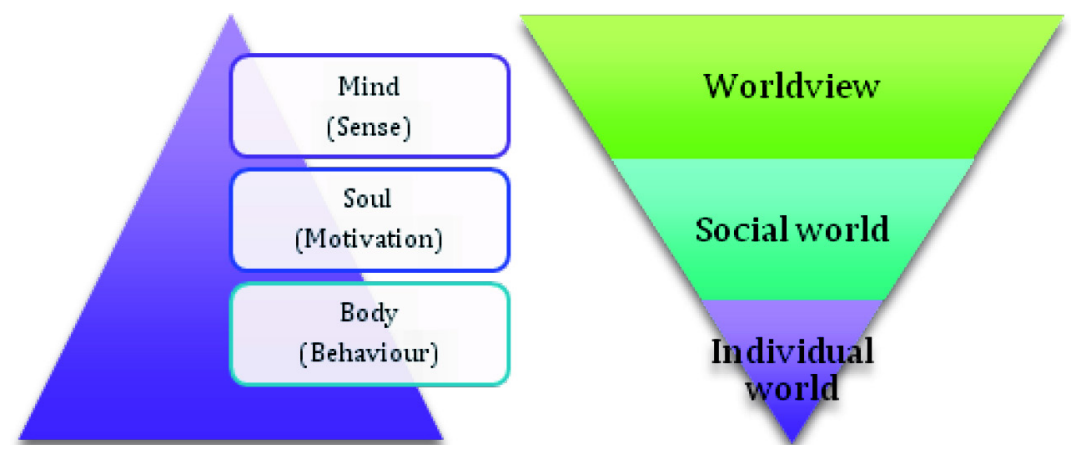

Figure 1: The dimensions and levels in the concept of human nature

Source: based on Horodecka (2014b)

\footnotetext{
3 The macro-level, which reveals the basic relations between humanity and nature and between humanity and supra-nature - metaphysics.

${ }^{4}$ It informs us about the nature of basic relations within society.

${ }^{5}$ Some concepts of human nature stress the fact that decisions are not rational but only guided by emotions and motives. Some highlight the rational aspect of human action, others consider both of them.
} 
Having given a broad idea about the central issue of this paper and its importance, the following two sections of the paper introduce the main differences regarding the concepts of human nature using the example of evolutionary economics contrasted with neoclassical economics. The next section deals with the definitions and denominations of these economic schools and their sources. This task is a real challenge as both schools (i.e. neoclassical and evolutionary economics) have no clear definitions and borders that would be accepted by all economists. Nevertheless we can make an attempt to approximate the field of the schools.

Neoclassical economics is understood as a direction in economics that can be traced back to the following thinkers responsible among other things for the marginal revolution and equilibrium theory: Hermann Gossen (1854), William Stanley Jevons (1888), Leon Walras (2013), Francis Edgeworth (1881), Irving Fisher (1892) and Vilfredo Pareto (1909). According to Mirowski (1999: 194), their work constituted a fundamental break with the economics of their time. The beginning, according to Ekelund and Hebert (1997), can be dated back to the 1840s, and some authors count it among the fundamentals of mainstream economics; some, like Colander (2000), speak of the death of neoclassical economics. According to Bartkowiak (2008), the marginal revolution has to be set in the 1870 s, but the ideas were formed earlier by Say (1803) - the subjectivist approach, and applied by Ricardo (1815). They were inspired by their precursors, like von Thünen (1826), Cournot (1838), Dupuit (1844) and Gossen (1854). The main assumptions of this paradigm are encrypted within the neoclassical model of Man, for instance the independence of preferences, rational choice based on optimization decisions according to preference curves and the marginal approach to calculating costs and utility (Horodecka, 2014a).

The predominance of the objective methods in neoclassical economics can be considered as a consequence of the deliberate focus on the one primary motive of human decisions, namely utility maximization. Considering more motives, emotions and geographical and historical contexts in concepts of human nature requires the application of new methods by economics. Thus it can be assumed that more than one motive in the concept of human nature requires more sophisticated modelling than a simple optimization equation. Similarly, the assumption of the impact of other persons on the decision makers remains in opposition to the neoclassical assumption of the interdependency of individual choices.

However, some economists no longer perceive the neoclassical paradigm as dominant within mainstream economics. Colander (2005a, 2005b) and 
Davis (2006) maintain that it has been replaced by a variety of different approaches. These approaches consider the discoveries made on the borders of orthodox economics adapting heterodox ideas. Consequently some economists seek an alternative paradigm or approach. Colander et al. (2004) argue that economics is currently undergoing a fundamental shift in its method away from neoclassical economics and towards something new. Some of them, according to Kwaśnicki (1996), come to modern heterodox thought, namely in evolutionary economics. It can be integrated with or replace neoclassical economics, so it is worth considering. ${ }^{6}$ More and more economists, for instance Collins et al. (2015), speak about the evolutionary foundations of modern economics.

Evolutionary economics is rooted, according to Kwaśnicki (1996), in four different intellectual traditions: the Austrian economic school (for instance Hayek, 1980), the Schumpeterian tradition (initiated by Schumpeter, 1911), institutionalism (starting with old institutionalism initiated by Veblen, 1967) and the western Marxist school (Marx, 1990). However, the roots of biological analogies so characteristic of evolutionary economics, can be found earlier as well in the work of Marshall (1920). The Mecca of economists lies in economic biology rather than in economic dynamics. For Schumpeter (1954), Marshall's theory ultimately represents an evolving theory. Other roots can be seen in the idea of economic development by Adam Smith (2005). Finally, a wide philosophical background of evolutionary ontology is delivered by Alfred Whitehead, Charles Peirce and Henri Bergson. Of course we cannot forget about the ideas of Darwin, who describes his theory as the theory of Malthus adapted to the whole animal and planet realm. According to Dopfer (2001), it was Veblen (1898) who introduced the term 'evolutionary economics' into the discipline. We also cannot forget about the contribution of Friedrich Hayek (1945: 532), who sees the essence of the modern market economy in the distinctive complex and accelerated evolution of knowledge.

Having such a rich background, evolutionary economics is a particularly differentiated and rapidly developing school in modern economics. The present state of evolutionary economics can best be characterized by Kwaśnicki (1996: 75) as a new heterodoxy in economic thinking. Fritz Söllner (2001) suggests distinguishing three different streams within this

\footnotetext{
${ }^{6}$ According to Kwaśnicki (1996), we can observe the co-evolution of two ways of dealing with technological progress. They are manifested in the adoption of some evolutionary ideas into neoclassical economics. An example is the neoclassical interpretation of economic evolution (Lehmann-Waffenschmidt, 1990).
} 
school. He takes as a criterion the way of dealing with the idea of evolution. The first approach adopts the idea of evolution as a biological metaphor, useful heuristics, which allows economic phenomena to be explained. Although the approach is sceptical towards neoclassical economics, it does not create new economic theories and thus is open to all economists. The second stream, which includes Alchian (1950) and Nelson and Winter (1982), looks for economic parallels to biological phenomena. It explains these analogies with biological laws.7 The third direction represents the reductionist approach, which reduces economic phenomena to their biological roots. It is inspired by socio-biology, which seeks biological reasons for social behaviour (Wilson et al., 2013). Evolutionary economics, according to this latter stream, is concerned with explaining the process of building preferences based on evolutionary theory (Becker, 1976a: 826). This direction of evolutionary economics includes economic imperialism, represented by Hirshleifer $(1977,1978)$, for whom socio-biology and economics are only parts of meta-economics, which deals primarily with competition and limited resources. In this paper evolutionary economics will be understood in the sense of the second approach, which represents a middle way between the first and the last one.

Many evolutionary economic ideas can be found in other economic schools and their representatives. To avoid confusion when referring to authors who represent two or more schools (or referring to ideas that are common to diverse schools), some of the intersections will be discussed.

One of the intersections can be found between evolutionary economics and complex economics. It should be stressed that complex economics is not 'an add-on to standard economics' (Fontana, 2010), nor can it be reduced to adding agent-based behaviour to standard models. Rather, it is a different way of thinking about the economy, namely as a system that is not in equilibrium but in motion, continuously 'computing' itself and constructing itself anew (Arthur, 2015b, 2015a). This idea is very close to the evolutionary ideas of creative evolution.

Similar intersections can be seen between institutionalism and evolutionary economics. Hodgson (2007: 20) defines the common scope of the two, stating: "A major priority for evolutionary and institutional economists is to develop a theoretical alternative to replace the neoclassical equilibrium approaches that previously held sway'.

\footnotetext{
${ }^{7}$ For biological phenomena economists seek an economic analogy and apply the biological law to it.
} 
We can see them further between ecological economics and evolutionary economics, following Lee (2009). Such intersections are characteristic of modern heterodox thought and are correlated with the fact that these economists are working on the borders of two schools and are counted in one or both of these schools (for instance Hodgson, 2007).

To overcome the problem with intersections, the author has chosen the ideas of evolutionary economics that build its essence (referred to by most evolutionary economists) and are oriented towards the evolutionary theory using their main ideas, concepts and terms. ${ }^{8}$ The ideas of evolutionary economics about human nature (implicit and explicit) are confronted with the most standard understanding of neoclassical economics, taking apart ideas that are developed on the borders of neoclassical economics.

\section{DIFFERENCES BETWEEN CONCEPTS OF HUMAN NATURE IN NEOCLASSICAL ECONOMICS AND EVOLUTIONARY ECONOMICS}

The concepts of human nature on all three levels usually have a philosophical basis. Neoclassical economics seems to be based in its worldview and concept of human nature on a dualistic system, supported by deistic religious thought, which is based on the idea that the material world is a perfect machine developed by God. To understand its functioning, the laws of nature have to be discovered in an objective way. The other part of this dualistic world is the spiritual one and encompasses diverse feelings and tensions which, however, cannot be described. The philosophical fundaments of the social world of neoclassical economic thought are delivered by the 'Leviathan' of Hobbes (1588-1679) (Hobbes and Macpherson, 1987), who stresses the egoistic and competitive character of human relations. The basic idea for the individual dimension is grounded on the hedonistic and utilitarian thought developed by Bentham and Mill (1973), which has its origins in ancient Greek philosophy (by Epicurus, 341$-270 \mathrm{BC})$. Another important source of this concept can be traced back to Hume (2007b), whose concept of human nature is based on empirics (Book I, part 3). For Hume (2007b) such a principle is sympathy, which delivers an explanation of human motives and actions. The validation of actions is

\footnotetext{
${ }^{8}$ According to Hodgson (1993), the understanding of these concepts (like adaptation, fitness, genetic variation, ontogeny and phylogeny) has differed during the tradition of evolutionary economics.
} 
utilitarian in the sense that the criterion of the choice is the utility. Interestingly, there are also rules of conduct other than utility, like justice, which can be considered as "steadfast and immutable; at least, as immutable as human nature" (Book III, part 3). In the end, justice is considered as the rule that brings the greatest utility for the individual. These opposite sides of human nature were later captured in the two books by Adam Smith, reflecting the sympathetic and egoistic nature of humans. The second one is characteristic of economic decisions and the first of other aspects of life. According to Taylor (2004: 48), they only aimed to separate these two types of motives, but the reality was the effect of the interplay between the two.

The philosophical basis of evolutionary economics can be traced back to Heraclitus (535-475 BC), who assumes that the principle of the world is a permanent change (Пóv $\tau \alpha \tau \rho \varepsilon 1$ (panta rhei) 'everything flows' - a sentence that is attributed to him by Simplicius). We cannot drop twice into the same spot of water. Evolutionary economics assumes in a similar vein that the whole world and its systems, culture and economic process change. Further philosophical sources of evolutionary economics could probably be found in the philosophy of life, ${ }^{9}$ with the idea of the universe as an irrational place, developed by Schopenhauer (1819), but the best accountable philosophical setting of evolutionary economics is the theory of Darwin (1859) ${ }^{10}$ more strictly the 'neo-Darwinian synthesis', which, according to Lennox (2010), deals with the following philosophical issues: probability and chance; the nature, power and scope of selection; adaptation and teleology; nominalism vs. essentialism about species; and the tempo and mode of evolutionary change. Dawkins $(1981,1995)$, interpreting this thought, perceives the meaning of the world as passing on genetic material and adjusting it further with each stage of evolution.

Table 1 presents the most striking differences between the worldviews of neoclassical economics and evolutionary economics. Although some other categories could be integrated into the analysis (like the existential, aesthetic, perceptual, cosmogonic and cosmological categories suggested by Kwasnicki, 1996), the choice here was constrained to those aspects that can

\footnotetext{
${ }^{9}$ For the connections between the philosophy of life and economics, see Horodecka (2011a).

${ }^{10}$ Darwinist philosophy - Darwinism is concerned with some important philosophical aspects aroused by his theory, although Darwin was not a philosopher par excellence. As Lennox (2010) explains: "Charles Darwin was not, as we use the term today, a philosopher, though he was often so described during his lifetime. Nevertheless, for an encyclopaedia of philosophy what is needed is a discussion of the impact of philosophy on Darwin's Darwinism, and the impact of Darwin's Darwinism on topics that both he, and we, would consider philosophical."
} 
be found directly in both of the analysed economic schools and that therefore have an impact on the understanding of the field, theory and goal in economics.

Table 1

Worldviews of neoclassical and evolutionary economics

\begin{tabular}{|c|c|c|}
\hline & $\begin{array}{c}\text { Worldview of neoclassical } \\
\text { economics }\end{array}$ & $\begin{array}{c}\text { Worldview of evolutionary } \\
\text { economics }\end{array}$ \\
\hline $\begin{array}{l}\text { Relation to nature/ } \\
\text { supernature } \\
\text { Material/ immaterial } \\
\text { character of the } \\
\text { world }\end{array}$ & $\begin{array}{l}\text { - Newtonian/Cartesian image of the } \\
\text { world } \\
\text { - Material phenomena (non-material } \\
\text { ones do not have an impact) }\end{array}$ & $\begin{array}{l}\text { - Darwinist/neo-Darwinist image } \\
\text { of the world } \\
\text { - Non-material and material } \\
\text { phenomena }\end{array}$ \\
\hline $\begin{array}{l}\text { Stability/dynamic } \\
\text { nature of the world }\end{array}$ & $\begin{array}{l}\text { - The world is stable from a long- } \\
\text { term perspective but in the short } \\
\text { term it is not always balanced } \\
\text { - There is equilibrium in a } \\
\text { thermodynamic sense, an optimal } \\
\text { state }\end{array}$ & $\begin{array}{l}\text { - The world changes (dynamic); } \\
\text { the law of a self-organized } \\
\text { change and self-transformation } \\
\text { - There is no equilibrium and no } \\
\text { optimal state }\end{array}$ \\
\hline $\begin{array}{l}\text { Humanity/nature } \\
\text { characteristics } \\
\text { Independency/ - } \\
\text { dependency }\end{array}$ & $\begin{array}{l}\text { - The world consists of separate } \\
\text { independent objects } \\
\text { - Independent (atomistic) } \\
\text { - Humans do not depend on the } \\
\text { environment }\end{array}$ & $\begin{array}{l}\text { - The world is like a holon } \\
\text { (holistic approach) consisting of } \\
\text { an interdependent net of objects } \\
\text { - Interdependent, dependent } \\
\text { - Humans depend on the } \\
\text { environment }\end{array}$ \\
\hline $\begin{array}{l}\text { (Un)predictability/ } \\
\text { (in)security }\end{array}$ & $\begin{array}{l}\text { - The world is something predictable } \\
\text { and secure for human beings and } \\
\text { can be described by laws }\end{array}$ & $\begin{array}{l}\text { - The world is unpredictable and } \\
\text { insecure; therefore, people look } \\
\text { for some patterns that work }\end{array}$ \\
\hline $\begin{array}{l}\text { Access to } \\
\text { information }\end{array}$ & $\begin{array}{l}\text { - Full access to information resulting } \\
\text { in rational decisions } \\
\text { - Humans are perfect machines that } \\
\text { can transform all information }\end{array}$ & $\begin{array}{l}\text { - Restricted access to information } \\
\text { - Transformation of information is } \\
\text { also not perfect (bounded } \\
\text { rationality), based on rules }\end{array}$ \\
\hline
\end{tabular}

Source: Horodecka (2015a).

Table 2

Relations between human beings in neoclassical economics and evolutionary economics

\begin{tabular}{l|l}
\hline \multicolumn{1}{c|}{ Neoclassical economics } & \multicolumn{1}{c}{ Evolutionary economics } \\
\hline Preferences are coined individually & $\begin{array}{l}\text { The choices of one person are influenced by the } \\
\text { choices of others/society }\end{array}$ \\
\hline Egoistic self-interest & Egoistic and altruistic interests \\
\hline Self-sufficiency & Interdependency \\
\hline Competition & Cooperation and competition \\
\hline
\end{tabular}

Source: own compilation; see also Horodecka (2015a). 
The most important differences between evolutionary and neoclassical economic thought referring to the social world are presented in Table 2.

Neoclassical and evolutionary economics differ strongly in their general assumptions about humans (see Table 3). According to Hodgson (2007: 16), the evolutionary concept of human nature is very close to that suggested by institutional economics, especially when it comes to the limited, deliberative and calculative capacities, and historical school. As evolutionary economics has its roots in institutionalism, the concept of human nature is close to the institutionalist concept of human nature. The concept of human nature as it is presented by Veblen (1898) is characterized by good and bad instincts. The instinct of workmanship is good and responsible for the creation of technological institutions. On the other hand, the instinct of competition and non-satiety instincts, which are sources of ceremonial institutions like property laws and financial systems, count among the bad instincts (Bartkowiak, 2008). The concept is in many aspects similar to the one developed within socio-economics. The economic actor is understood there, according to Jensen (1987: 1069), as a socio-cultural person whose behaviour and actions are determined mostly by a socio-cultural environment evolving continuously under the impact of dynamic technological forces. Moreover, a person pursues a multiplicity of goals and objectives.

On the contrary, neoclassical economics deliberately starts its analysis not with the real man but with an idealistic type - a standardized, homogeneous and representative being (Aruka and Mimkes, 2006: 146), who is a rational (only goal-oriented rationality counts), self-sufficient and egoistic optimizer, calculating the best result for him/herself and pre-formed by nature in that way. ${ }^{11}$ This image of Man has many characteristics that are not congruent with the reality. ${ }^{12}$ The nature-nurture problem is solved here to the credit of nature. Furthermore it is assumed that human beings are stable, context-free and do not change due to time and space. The dualistic vision of human beings makes economics deal only with one part of individuals (Szarzec, 2002) - the materialistic part, which resembles an atom. Therefore, this vision of man is, according to Klimczak (2000: 11-29), very reduced, "to the mere basics".

\footnotetext{
${ }^{11}$ For the differentiation between idealistic and generalized concepts, see Thies (2004).

${ }^{12}$ We refer here to Georgescu-Roegen (1971) about the fiction of homo oeconomicus. However, it is not necessarily the weak point. In many theories the instruction of idealistic types proposes to be useful for goals of discipline.
} 
Just the opposite is assumed in evolutionary economics in which, at the very beginning we deal with a complex, reality-close human being - a satisfier who seeks not to optimize his/her needs but to be in balance with the environment. He/she is sub-rational, not self-sufficient, both egoistic and altruistic, adapts to the environment through learning and thus changes. There is no such thing as the representative actor: agents are heterogeneous (Wagner, 2011: 305). Moreover, human nature can be treated as a holon with many different dimensions. The nature-nurture problem is solved in evolutionary economics by respecting both genetic influence (nature) and adapting through learning (nurture). There is no place for individualism because the individual is embedded in the changing world, society and culture and is always perceived contextually. Besides, it is not the individual who is in focus but the 'gene' - information which takes the form of knowledge and is passed to other organisms. In this sense a human being is less a fixed object and more a process, which changes with time/place and depends on the environment. This means that human beings are very heterogeneous, also due to the differences caused by culture and time, which are neither accidental nor random, according to Aruka and Mimkes (2005). This assumption is central to the understanding of any phenomenon (for example economic growth).

Table 3

Individual dimensions of the concept of human beings - the main differences between neoclassical and evolutionary economics

\begin{tabular}{l|l}
\hline \multicolumn{1}{c|}{ Neoclassical economics } & \multicolumn{1}{c}{ Evolutionary economics } \\
\hline $\begin{array}{l}\text { Natural man - rational, self-sufficient, } \\
\text { egoistic, preformed so by nature (nature) }\end{array}$ & $\begin{array}{l}\text { Evolutionary man - sub-rational, not self- } \\
\text { sufficient, egoistic and altruistic, adapting to the } \\
\text { environment by learning (nurture) }\end{array}$ \\
\hline $\begin{array}{l}\text { Individualism, context-free standardized } \\
\text { individual, representative }\end{array}$ & $\begin{array}{l}\text { Embedded in culture, time, society and } \\
\text { environment; the transfer of knowledge is central }\end{array}$ \\
\hline Homogeneity & Heterogeneity \\
\hline Static, unchangeable & Process, changing (over time and place) \\
\hline $\begin{array}{l}\text { Only the material side of human nature } \\
\text { counts }\end{array}$ & $\begin{array}{l}\text { The material and idealistic sides of human } \\
\text { nature are considered }\end{array}$ \\
\hline $\begin{array}{l}\text { Dualistic concept of human beings } \\
\text { (economics deals with only the material } \\
\text { part) - ATOM }\end{array}$ & Holistic concept of human beings - HOLON \\
\hline Reality - distance & Reality - closeness \\
\hline Reduced (simple) & Complex \\
\hline Optimizers & Satisfiers \\
\hline
\end{tabular}

Source: own. 
Looking more closely at human nature we can point out differences on each level (body, soul and mind) between those economic schools.

Neoclassical economics assumes human behaviour to result from egoistic motives. These motives are grounded less in real needs and more in preferences, which means that theoretically a person can alter any need according to his/her preferences. Changing preferences is only a logical problem; any need can thus be satisfied by another product, and this replacement is ruled by the preference curves (whereby only tradeable end results count). This assumption is criticized by evolutionary economics as being very unrealistic because in reality some needs cannot be replaced (for instance the need for fresh water or air) and can only be surpassed or modified (biological reasons) (Sen, 1999; Nussbaum, 2003). This is because the needs are made by nature and society, some of them have to be met by necessity. Evolutionary economics also considers, among the needs, process needs ${ }^{13}$ such as labour. A human being acts to fulfil those needs both egoistically and altruistically.

The differences are therefore visible in the soul dimension, consisting of feelings, emotions and motives. Whereas neoclassical economics focuses on pleasure/utility as the main motive, evolutionary economics criticizes it for various motives and values, acknowledging that some are grounded more deeply in biology (utility as fitness) and social life (ethical principles). ${ }^{14}$ Some authors suggest interpreting utility as fitness (Rubin and Paul, 1979). All these motives change continually through interactions with other people. ${ }^{15}$ Of course, neoclassical economics does not exclude values and other motives. If some ethical values associated with a particular choice have a utility for somebody, he/she would choose them.

The last dimension is the mind - a place for reasoning and spirituality. In neoclassical economics the mind is implicitly regarded as an important instrument used for calculating the right decisions based on preference curves and the available resources. Only goal-oriented rationality is taken into consideration. Neoclassical economics makes many other implicit assumptions about human abilities concerning rational choice, data collection, cognition,

\footnotetext{
${ }^{13}$ Some needs cannot be fulfilled by acting egoistically, which is clear if we think about our daily experience with people - no friendship, partnership or even simple working relation can work properly if we act only egoistically.

${ }^{14}$ According to Kenrick et al. (2009), people make decisions according to a set of principles that often do not make sense at a superficial level.

15 The idea of endogenous preferences in evolutionary economics can be traced back to institutional economics; the same applies to the idea of bounded rationality.
} 
computation and execution, assuming perfect information (zero informationgathering cost), infinite computational capacity (zero calculation cost) and unlimited execution capability (zero management cost, according to Nishibe, 2006: 7). The assumption of the independence of individuals in the process of decision making leads to one of the reasons for understanding knowledge as a resource (similar to money or labour invested in a production process), without explaining the process of its acquisition.

The opposite is the case of evolutionary economics; the calculating power of the mind is not as perfect as in neoclassical economics due to the assumption about 'bounded rationality' (a term coined by Simon, 1957b). This term refers to the fact that during the process of making a decision our rationality is reduced by incomplete information, cognitive boundaries and time boundaries. ${ }^{16}$ Instead of rationality, actors (people, firms) use routines ${ }^{17}$ which take the shape of routinized behaviour, conventions and social rules of conduct (see Nishibe, 2006: 21). Those rules are the persistent feature of an organism and determine its possible behaviour; moreover, they are 'heritable'. According to Nelson and Winter (1982: 14), organisms with certain routines may perform better than others, and therefore their relative importance within the population (industry) is augmented with time. They are part of the knowledge and similarly cannot be bought like a resource; they are a product of society and can only be assimilated by learning (Söllner, 2001). The real role of the mind consists much more of finding the right rules and helping the human being to adjust to the environment and on the other hand to self-actualization. ${ }^{18}$

\section{INFLUENCE OF THE CONCEPT OF HUMAN NATURE ON THE METHODOLOGY OF ECONOMICS}

The concept of human nature influences the foundations of economics. These are the goal, the field and the methodology of economics. ${ }^{19}$ One of the basic elements of these foundations is the methodology and thus the methods

\footnotetext{
${ }^{16}$ According to Simon (1957a), agents experience boundaries in formulating and solving complex problems as well in the processes of receiving, storing and retrieving and transmitting information. People taking decisions have to decide when and how they will take the decisions.

${ }^{17}$ Nelson and Winter (1982: 14) write: 'in our evolutionary theory, these routines play the role that genes play in biological evolutionary theory'.

${ }^{18}$ The mind plays a similar role in humanistic economics.

${ }^{19}$ For an understanding of the field and goal of evolutionary economics, see for instance Horodecka (2015a).
} 
and the basic theories. The concern of this paper is to show the influence of these concepts on the different aspects and topics within the methodology of economics.

Methodology can be understood as the set of methods, rules and ideas that are important for a science or art. It is a design process for carrying out research. In other words it is a general research strategy, creating the way for research projects to be undertaken.

The impact of the concept of human nature on methodology can be explained in the following way. Philosophy with its sub-disciplines, like philosophical anthropology, provides a setting for the concepts of human nature conditions with the sub-discipline epistemology, part of which is the philosophy of science. The philosophy of economics is considered as its subdiscipline and deals with the methodology of economics, which predefines the proper methods for diverse research designs. Finally, theories are developed on behalf of methods considered as proper by the methodology (Horodecka, 2011b).

\begin{tabular}{l} 
Philosophy $\rightarrow$ Epistemology $\rightarrow$ Philosophy of Science $\rightarrow$ Philosophy of \\
Economics $\rightarrow$ Methodology of Economics $\rightarrow$ Methods $\rightarrow$ Theory \\
\hline
\end{tabular}

The importance of the methodology can also be seen in the last segment of this sequence above - the economic theories which can, according to Hardt (2013), deal with two basic issues - (1) phenomena and (2) structures, mechanisms and tendencies - and the influence of the latter on the former. ${ }^{20}$

There are different methodological issues which can be distinguished from the observation of the methodological tendencies in economics presented by Backhouse (1996), Blaug (1997), Caldwell (2001), Hausman (2001), Davis (2003) and Samuels et al. (2003). Horodecka (2013) presents the different issues discussed within economic methodology after the 1970s, as a consequence of the changes in philosophy. The changes in philosophy can be considered as the factors that are responsible for the modification of the concepts of human nature (Horodecka, 2015b). These issues encompass, for instance, the question of whether economics is positive or normative. Furthermore, they include questions about the predominance of abstraction or idealization, the reasons for individuals' actions, ${ }^{21}$ the structure of

\footnotetext{
${ }^{20}$ According to Lawson (2004), science has to deal not only with phenomena but also with structures (empirical, factual and real), mechanisms and tendencies, otherwise it would be downgraded to epistemology.

${ }^{21}$ Are the decisions deductive (based on assumptions) or are they inductive (observed empirically and contextually)?
} 
research programmes in economics, ${ }^{22}$ the problem of the growing complexity of phenomena, criticism of the reductionism of abstract models and the attitude towards pluralism in economics. These issues are discussed in the context of many different approaches to the philosophy of science such as pragmatism (Poirot, 2008), realism (represented by Mäki, 1990, 2002, 2006; Hardt, 2013), constructivism (Zboroń, 2009) and the rhetorical approach of McCloskey (1986). ${ }^{23}$

There are profound differences between evolutionary economics and neoclassical economics in their views on methodological issues. These may have their sources in their assumptions about human nature. The differences in methodological issues lead further to different preferences for the methods applied in the research and in their consequences for different theories which are developed using those methods and based on the methodological considerations.

The methodological issues are grouped into specific categories and discussed below. These are: (1) basic metaphors; (2) ontological issues, (4) epistemological problems and crucial terms, (5) the approach to inter- and multidisciplinarity ${ }^{24},(6)$ the way of arriving at scientific statements and the conviction about what is scientific, 7) general features of the methodology (like the approach to the question of methodological individualism); 8) basic assumptions - principles and hypotheses; 9) the main unit of research; 10) the scientific approach (descriptive, positive or normative); and 11) metamethodological issues.

In the following part of the paper these distinguished methodological topics will be compared, taking as an example neoclassical and evolutionary economics. Firstly, it will be explained why these issues are important for methodology; secondly, the differences will be explained; thirdly, the possible reasons will be elaborated in reference to different concepts of human nature.

\footnotetext{
${ }^{22}$ It asks for instance whether the structure of research is a logical consequence of the up-todate research, like logical positivism. Alternatively, it is a consequence of other factors that are independent of science, for instance the demand for some topics and monetary issues, as perceived by e.g. mainstream economics. On the contrary, the institutional tradition, and therefore evolutionary economics, recognizes the meaning of the social context as well.

${ }^{23}$ The methodology of economics as the practice of rhetoric and persuasion, thus substituting the classical idea of a skill or an art for the modernist, epistemological idea of science as a body of knowledge.

24 As a methodological approach to solving economic problems by acknowledging the necessity of cooperation with other disciplines and the insufficiency of economic thinking.
} 


\section{(1)Basic metaphors and paradigms}

The metaphors used within science in general and within economics, create a cognitive meta-map of phenomena showing how we perceive the world and its elements. When we replace a metaphor with another metaphor which differs substantially, we might speak about the paradigmatic change. For instance, for many centuries the main metaphor used for explaining the world and all its phenomena placed the Earth and human beings at the centre of the world. As soon as the Copernican change surpassed only physical sciences and reached philosophy as well, this idea was replaced by the conviction that the Earth and human beings are only some simple determined elements in the world order. This had a great influence on science, the philosophy of science and methodology.

Those views reflected the dominant concept of human nature. The first one referred to the concept of a human as a mirror of the world, the centre, the crown of beings, responsible for other creations and having a free will and the possibility to change. The second one referred to a predetermined human being, whose function was described by the world order.

Neoclassical economics is (due to the time and place of its development) the inheritor of the second worldview and therefore the basic approach to the world is determined by perceiving it as a deterministic system guided by some universal and timeless laws which we have to discover. Consequently, the main science on which the economic models are grounded is physics, which aims to discover general, unchangeable laws in an objective way and in which the human being is considered as just one of many physical objects in terms of traditional, Newtonian physics (Hodgson, 1993). ${ }^{25}$

In evolutionary economics a different metaphor predominates, owing mainly to Charles Darwin and his view of the world as a place of evolution, in which the main rule for perceiving the world is change. There are some crucial factors that are responsible for it. Biology appears to be the crucial discipline which can be adapted to explain not only strictly biological phenomena but all of them. This view underlies some transformations from perceiving the world from outside without a time/place perspective, which asks about the forces explaining the stability of the world, to perceiving the world from inside, asking for forces explaining changes within the living

\footnotetext{
${ }^{25}$ Contemporary physics has developed a different approach in such a different way that we can speak here about a paradigmatic change. Modern physics describes the world in terms of probability (the object is in one place only with some degree of probability).
} 
organism. ${ }^{26}$ Although the current evolutionary economics has its roots in the science of biology and the scientific discoveries of Charles Darwin, it was economics (political economy) that influenced biology during the eighteenth and nineteenth centuries. The thinking on evolution in the economics of Bernard de Mandeville (1670-1733), Adam Smith (1723-1790) and Thomas Malthus (1766-1834) contributed to the birth of Charles Darwin's (1809-1882 ) theory of evolution. Such a view is an effect of the changing perspective on human beings. Human beings are not any part of the stable system but the active part inducing changes in the world. The changes in human beings have an impact on all other objects. These issues are also discussed by Hayek (see Rembold, 2006) and by Hodgson (1999b, 1999a, 2001, 2005, 2007, 2012, 2013). However, they were developed later than those mentioned above.

A further metaphor concerns the way of perceiving the relations between phenomena. This metaphor is also a consequence of the worldview. Neoclassical economics (applying its physical worldview and using its atomistic metaphor) assumes that all objects are separate and independent, synchronized by the market forces. Evolutionary economics perceives phenomena as interdependent, which is a consequence of its holon metaphor used for the description of the basic relations between humanity and nature (the first basic dimension of the concept of human nature).

A further methodological issue is the paradigm which builds the foundations of each science and depends on the assumptions about human beings. ${ }^{27}$

In neoclassical economics the basic paradigm is a result of the new concept of human nature, which emerged during the Enlightenment. It was a simplified view of a person in comparison with the anthropological tradition of this time. The human being was consequently treated more and more as part of the whole deterministic world system ruled by some laws. Therefore to understand the behaviour and actions of a person, the physics is required and no longer the philosophy. As a consequence the metaphors, theories and ways of thinking of neoclassical economics are no longer derived from philosophy ${ }^{28}$ but are oriented towards natural science. ${ }^{29}$ The core here is

\footnotetext{
${ }^{26}$ Accordingly, biology is a historical science, like the phenomena that it describes. Changes in time are historical.

${ }^{27}$ A paradigm is a set of basic assumptions, metaphors that are used as a basis for all the theories that are constructed within it.

${ }^{28}$ As in ancient or medieval philosophy or even by Adam Smith, who was a moral theologian (part of practical philosophy).

${ }^{29}$ Interestingly, even David Hume investigated the questions about human nature, searching for fixed laws, as mentioned before.
} 
physics focused on discovering general laws which are always true. To determine these laws, some assumptions about the objects that we describe have to be made. Newtonian physics focuses on the description of physical objects which can be characterized by some properties (for instance mass) and obey some laws (like the law of gravitation). Accordingly, in economics there are assumptions about the economic world and economic objects. These economic objects are especially humans and specifically their behaviour. Looking for general laws governing individual behaviour, neoclassical economics has developed, for instance, the 'law' of maximizing utility. In a similar way the laws concerning a social world were developed, one of them might be the strong conviction that the orientation towards own interests builds the best result for all. This also affects the next dimension of the concept of human nature, the worldview led by the law of equilibrium. This law says that there is a steady-state point to which all processes caused by free movements of objects (homogeneous but independently acting actors) are tending. The laws of thermodynamics are the best physical metaphor that can be used here to illustrate this balance. Economic objects and actors behave like independent particles in a particular way, which, by force of the law of nature, always tend to the optimum (balance point). In the textbooks on economics, this paradigm is often presented in the form of a picture of an object always returning to the steady-state point (for instance by Bartling and Luzius, 2000).

Evolutionary economics is based on a completely different paradigm which harmonizes with the basic biological metaphor. ${ }^{30}$ According to it, all economic processes are explained using such ideas as Darwinist variation, selection or the neo-Darwinist paradigm of mutation and selection. ${ }^{31}$ This is also the result of the changing understanding of human beings, perceived no longer as an element of the deterministic world but as part of a co-evolving system. In such a system there is no fixed steady-state point because there is no such thing as a stable world. The metaphor for this paradigm is completely new, which resembles the great paradigmatic change - the Copernican one. The parts of the economic system are no longer perceived as separate, fixed, independent from each other and unchangeable but as

\footnotetext{
${ }^{30}$ The idea that economics should be or will be based on the biological paradigm can be seen earlier (Marshall, 1920). For a century some economists have maintained that biology is a more appropriate paradigm for economics than equilibrium models with analogies to mechanistic ones.

31 According to Andersen and Holm (2014), there are three sorts of selection: stabilizing (removing others), directional (coexistence) and diversifying.
} 
elements that are adapting continually to the environment. As a consequence, all actors are heterogenic, changing in time and place (cultural factors) and adapting to the changes that happen in the environment (other people, nature and culture). Actors who adapt better survive, and in this sense we can speak about progress. Thus, for evolutionary economics the world is a complex system of interdependent, heterogeneous parts, an open system, or autonomous in the sense of Luhmann (1994), based on the principle of self-reorganizing change. Similar to ecological economics, evolutionary economics is sceptical about the neoclassical idea of (unlimited) economic growth. Economics must be perceived as part of the whole ecological system, which means that it cannot be extended infinitely. The elements that evolve are complex mechanisms, similar to the multifeedback network formed by genes and proteins as a control mechanism, sustaining a diversity of genes and adapting to various environmental changes (Kaneko and Kodama, 2004). This idea is expressed by the concept of stratified ontologies presented by Lawson (1997), including bi-directional causality and the emergence of novelty. Economic phenomena are exemplified using the concept of social evolution and the principle of stratified realism based on the ideas of Lamarck and Darwin (1859). According to this principle, social macro-systems exist as multi-polar and multi-layered structures (multi-lattice). Moreover, it is assumed that there is a permanent loop between the micro-level (the behaviour of agents and the emergence of new ideas) and the macro-level (rules, institutions, economic outcomes and the integration of those new rules into a deep structure of knowledge and auto-replicative processes). This idea of social evolution replaces the idea of genetic mutation and natural selection appropriate only for very simple organisms. The meso-level, according to Dopfer and Potts (2004, 2010), facilitates this transition and is responsible for the distribution process of these new rules. Each constituent of such a layer interacts horizontally with other constituents and is affiliated with multiple constraints on the upper level. Therefore, the biological metaphor has to be modified; the heredity should be understood as enduring and reproducing of some relations: rules, institutions, organizations, routines and customs. Social genes ('quasi' genes) have to be understood as more differentiated than biological genes. Furthermore, variation cannot be understood as a mutation or crossing but as an aberration from the norm, an innovation. The social domain is a fruitful ground for adapting the idea of Lamarck's inheritance which did not meet the requirements of empirical founding in the biological world. As a consequence the evolutionary economics world consists of: (1) a 
wide range of stratified entities of quasi-genes (customs, routines, conventions, social rules, institutions and economic systems); and (2) bidirectional causal relations between the micro-level of the behaviour of agents and the macro-level of the emergence of rules, institutions and economic outcomes. The process of evolution is modified by such factors as improvement/innovation through imitation and learning and differentiation/ diversification by the division of labour/ knowledge.

Summing up, we can say that, while the world in neoclassical economics is characterized by a propensity to stability, in evolutionary economics it is characterized by permanent change.

\section{(2)Ontological issues}

Ontological issues refer to the existence of things, the modus of existing

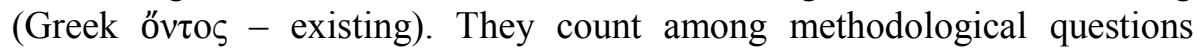
because they give an insight into the way of perceiving the phenomena. This has a deep consequence for epistemology, the way in which we may learn about those objects.

Neoclassical economics seems to have a rather materialistic view of the world as it allows for more objective results and facilitates comparisons better. Even love and friendship are reduced, for example by Becker (1976b), to materialistic outcomes. This is a consequence of assuming that a human being is a person who aims to maximize utility by buying goods and services of a primarily material character. ${ }^{32}$

Evolutionary economics assumes that the world and its objects are bimodal, having two contrasting ways of existence, the non-physical mode (information) and its material physical realization (matter and energy). ${ }^{33}$ It furthermore perceives reality as a process and not as a collection of objects. A further consequence which we can deliver from this worldview level of the concept of human nature (which is static for neoclassical and changing for evolutionary economics) is the attitude towards the nature of phenomena.

Neoclassical economics treats phenomena as not changing and stable.

\footnotetext{
${ }^{32}$ Of course, the neoclassical assumption of the subjective character of preferences allows economic actors to have either material or non-material preferences, as they are able to position them in their own preference hierarchy. This implies that a person is able to express them in any materialistic terms to compare them with other material needs.

${ }^{33}$ So-called 'evolutionary realism' can be presented using three axioms: (1) all existences are bimodal matter-energy actualizations of ideas, (2) all existences are associated, and (3) all existences are processes (Dopfer and Potts, 2010). A rule is both an idea and an actualization in matter-energy form. The bimodality is between the non-physical mode (information) and its physical realization (matter and energy); see Dopfer and Potts (2004: 8).
} 
The whole system is assumed to be independent and stable, and there is equilibrium in the thermodynamic sense. It is assumed that the economic system is independent from the ecological system thus there are no constraints put on the economic system regarding its energy usage.

Evolutionary economics applies a different approach, perceiving all objects and the whole system as changing. As the system always has to find a new equilibrium due to the impact of the environment, the entropy of such a system is always greater than 0 . It is assumed that real phenomena evolve and that they are matter-energy actualizations of ideas.

These aspects influence the particular interest in some issues within theories. Whereas neoclassical economics has, as some authors maintain, problems in explaining innovation ${ }^{34}$, for evolutionary economics both innovation and entrepreneurship are in focus. ${ }^{35}$

Consequently the methods applied to the analysis of phenomena are different. This is because the modelling of states and processes requires other methods. Similarly, the inclusion of the context in the analysis calls for other methods. Therefore, whereas neoclassical economics uses rather simple, testable models, evolutionary economics applies complex models, integrating the structure of the phenomena and their interdependency.

The assumption about the relation of idealistic and materialistic phenomena is another ontological consequence (referring to the way of perceiving objects). This relation is often discussed on the anthropological level as the so-called 'Leib-Seele' problem.

Due to the Cartesian view of the world, neoclassical economics assumes a strong division between the ideal and the material world and has a preference for material objects. It is assumed that there is no intersection between these two worlds. Even if the ideal world existed, it would not have any influence on the materialistic one, therefore neoclassical economics focuses in its research on the material world.

The completely different biological worldviews - the Darwinist view has another consequence for the assumed nature of the objects analysed in that they are dualistic - are both material and ideal (as mentioned before, they are matter-energy realizations) (Eparvier, 2005). In addition, importantly, there is an intersection between those two worlds. Science has to deal with both the physical and the non-physical world because the latter is crucial for the

\footnotetext{
${ }^{34}$ In primary economic growth models, technical progress (correlated with innovations) was treated firstly as a exogenous variable, later was explained by human capital.

${ }^{35}$ Nelson and Winter (1982) raised this problem, exploring the reason for that in their paper.
} 
understanding of the former. For instance, idealistic objects like information and knowledge are carried by material objects, persons and organizations. This happens similarly to the process occurring in the natural world in which non-material genes (=information) are carried by material objects.

\section{(3)Epistemological problems}

Epistemology deals with the issue concerning how knowledge develops, what kind of cognitive processes are possible and how we prove the knowledge (Steup, 2014). The ontological issues discussed earlier draw our attention to some basic concepts used in the methodology. Some of these also count among the epistemological issues as they tell us how the world of objects may be known and how it is actually known. They provide us with the cognitive map, the existence of basic phenomena, which then can be researched, learned and known. These topics are the concern of epistemology. The crucial terms and concepts therefore refer to some basic concepts that we use for describing economic phenomena. We assume their existence and relevance for providing further explanations.

For neoclassical economics such concepts are, for instance, a free market. Other concepts have a more epistemological character, facilitating the way of perceiving the reality. They play the role of spectacles through which we perceive the world, in other words they create our map of cognition and encompass such ideas as a stable-state point and utility. ${ }^{36}$ This narrows the horizon of the map, as not all objects that count can be measured by utility. ${ }^{37}$ Reducing the objects to such a construct may have an impact on the perception of the reality.

For evolutionary economics the following concepts are of importance: information, energy and knowledge as well as change, mutation and innovation. ${ }^{38}$ The further key notions of evolutionary economics, according to Nelson and Winter (2002: 23-46), are the selection, path dependency, chance and increasing returns. The research programme of evolutionary economics is based not on mechanistic analogies but on biological ones. This can be seen, as stated by Wagner (2011: 305), when it comes to

\footnotetext{
${ }^{36}$ The utility concept is used for ranking all objects according to their value for us.

${ }^{37}$ Some may be important or significant, but they cannot be or by assigning the utility we measure only one aspect of a phenomenon. We obtain diverse answers by asking about the utility of love for somebody and hearing of love for that person.

${ }^{38}$ According to Herrmann-Pillath (2000: 91), "The very essence of reality is information. Yet, we identify a primordial good, i.e. energy, which is a necessary condition for preserving and maintaining structures as storages of information".
} 
the usage of such terms as evolution, self-organized change and selftransformation.

The consequence of neoclassical economics' view of the world ${ }^{39}$ is the specific understanding of crucial terms and phenomena. Together with the assumption about the material character of the objects in the world, it results in the way of understanding the development captured here mainly in terms of quantitative growth. Moreover, permanent growth is regarded here as possible because the economic system is perceived as being independent from other systems.

The evolutionary worldview results in the understanding of the development in the completely opposite way. Thanks to the consideration of non-material aspects together with material ones, evolutionary economics pays greater attention to qualitative aspects of development. Consequently, development is understood as qualitative growth and is associated mainly with the growth of knowledge (non-material factor). Moreover, it is limited by the ecological system (similarly to ecological economics).

For neoclassical economics, due to its Newtonian worldview, economic objects will be perceived objectively. The assumptions made about humans and the environment facilitate the description of the world in numbers, using mathematical language.

Evolutionary economics uses another approach. Its research focus is more on looking for patterns ${ }^{40}$ and structures and less about numbers, therefore it does not rely on fixed, unchangeable assumptions. We can rather speak about some principles guiding the way of perceiving the reality. Part of the observed reality is an observer, therefore the research is not objective in the sense of neoclassical economics, it is rather intersubjective and contextual. A population of rules, structures and processes of rules is considered as serving to reduce the complexity (Dopfer and Potts, 2004: 496-512).

The additional epistemological issue is the role and the nature of models. For neoclassical economics the universal models which can be adapted, regardless of the cultural context, count as ideal models. Evolutionary economics builds so-called context-full models, which consider the role of the environment and of adaptation. This is due to the very assumption about human nature, adapting to the changing environment. In neoclassical economics the models mostly have a physical and mathematical character.

\footnotetext{
${ }^{39}$ It is based on the conviction that the economic system is independent from other systems.

${ }^{40}$ Nelson and Winter (1974: 893) state: "An evolutionary model of economic growth must be able to explain the patterns of aggregate outputs, inputs, and factor prices that neoclassical theory 'explains"'.
} 
Evolutionary economics prefers cultural and biological models, even if it also applies mathematics.

Furthermore, the difference concerns the usage of mathematical language by the construction of models. According to Granberg (1981: 42), neoclassical economics assumes that all existing objects can be modelled, therefore it deals with standard objects, aggregates and mathematical language in model construction.

Evolutionary economics advocates taking into consideration not only objects but also structures. ${ }^{41}$ Evolution can be perceived as the continuous or erratic/volatile deformation of model structures. This means a preference for indicators over aggregate variables and for statistical methods over mathematical ones in the analysis.

\section{(4)Approach to inter- and multidisciplinarity}

The idealistic character, therefore reduced to the most pregnant characteristics, of the concept of human nature in neoclassical economics (and not as a generalization) may be responsible for little interest in other disciplines. Neoclassical economics is based on the methodological ideal of physics, and even more it develops its own laws, which it applies to other disciplines. So, we can speak of economic imperialism or in this context of interdisciplinary approach even, but not of multidisciplinary one (Davis, 2016) ${ }^{42}$.

Therefore accordingly we can speak of the non-multidisciplinary character (as contrasted with the interdisciplinary one characteristic for economic imperialism). The assumptions made about human beings provide neoclassical economics with confidence in dealing with the economic behaviour of people. As a consequence it is not particularly interested in other disciplines.

On the other hand, evolutionary economics, assuming a complex concept of human nature, requires the help of other disciplines like biology, psychology and cognitivist sciences and represents a multidisciplinary approach. These disciplines are useful for understanding such issues as various motives, the time setting of decisions, cultural factors, adaptation processes to the environment and innovation.

\footnotetext{
${ }^{41}$ Therefore, for instance, there is much interest in models of conflict or synergy; see Haken (1977), Holub (1978) and Wagner (2011). The evolutionary economic methodology operates with the term dissipative structures. This is an analogy of thermodynamics to describe macro-economic processes explanatorily (German 'erklärend zu beschreiben'); see Wagner (2011: 307).

${ }^{42}$ Even the psychological laws of diminishing pleasure are originally economic ones.
} 


\section{(5)Way of arriving at scientific statements, conviction about what is scientific and methods}

The methodology delivers explanations about the way in which science and economics reach scientific statements. Hence the economic methodology explains what we consider as a scientific statement in economics and the methods and processes that we use to make them.

Neoclassical economics practices the deductive-inductive methodological process (suggested by Popper, 2002), which contains the testing of hypotheses. It is a consequence of the character of concepts of human nature, which is treated as some assumptions, which will help to make conclusions and determine propensity. Evolutionary economics, on the other hand, is more eager to use inductive methods based on observation. This is because it believes that only they deliver information about the adaption processes, patterns and rules, as they change. Some axioms (discussed in section 7) are helpful for understanding which elements and concepts have to be sought. ${ }^{43}$

Usually the methodology generates the question of whether and why some statements are considered as scientific and some are not. Neoclassical economics uses the criterion of objectivity here. This means that only the observable implications (or predictions) of a theory are considered to be true, which can be understood as the consequence of reducing the motivation level to utility maximization. This allows neoclassical economics not to ask about other motives, which would imply the use of intersubjective methods. Popper formulated here a very strong proof for the theory which states that if and only if an experimental implication of a theory proves false, the theory is proved false (Popper and Keuth (2005)). Moreover, the neoclassical methodology refuses to acknowledge the so-called subjective 'observation' (introspection), which is not considered as a source of scientific knowledge. As all important phenomena, due to the assumption about human nature, can be found at the 'body level', which can be approached by objective methods, there is no need to look for other methods. Although metaphysical beliefs and aesthetic statements may figure in the discovery of a hypothesis, they cannot figure in its justification.

In addition, there is a rule called Kelvin's Dictum according to which knowledge is only considered as such if it can be expressed in numbers. The physical worldview manifests itself, furthermore, in the assumption that a scientific explanation also seeks a covering law. Such an attitude has a consequence for the relative approach to values. Thus, neoclassical

\footnotetext{
${ }^{43}$ For instance, what is the knowledge in the firm, what are the patterns of behaviour, and what will be left as a heritage?
} 
economics treats values as already visible in the preferences made on the market by individuals. For neoclassical economics this is true because it is assumed that a person always chooses the most valuable option. ${ }^{44}$

This is congruent with the assumption about the concept of human nature. Homo oeconomicus is a model of Man that is constructed in an 'objective' way, which means that the model does not consider the existence of the 'inner world' of humans, which could possibly exert an impact on their decisions. There is only the 'outer world' - the behaviour. Homo oeconomicus is a model of human nature which refers only to the objective dimension of human nature, the 'body', accompanied by a fixed prevailing motive and reason able to calculate the utility of potential choices; consequently, we can focus only on the 'outer world'.

In contrast, evolutionary economics with its anthropological assumption concerning adaptation and changing preferences, adopts inductive, empirical methods, based on observation, which allows for discovering main adaptation processes and dominant structures, and the intersubjective approach, allowing for deeper understanding of the analysed phenomena, considering as well the 'inner world'.

Table 4

The influence of concepts of human nature in neoclassical and evolutionary economics on methods

\begin{tabular}{l|l|l}
\hline \multicolumn{1}{c|}{ Concept of human nature } & $\rightarrow$ & \multicolumn{1}{|c}{ Methods } \\
\hline $\begin{array}{l}\text { Neoclassical economics } \\
\begin{array}{l}\text { Atom, homogeneous, independent, } \\
\text { stable, reduced needs=preferences, } \\
\text { egoistic, competitive, rationality } \\
\text { oriented towards goals }\end{array}\end{array}$ & $\begin{array}{l}\text { Positive method, oriented towards natural } \\
\text { sciences } \\
\text { Formal models } \\
\text { Mathematical, ahistorical, acultural, because } \\
\text { the object of research does not change much, } \\
\text { formal, simple testable models }\end{array}$ \\
\hline$\downarrow$ & & $\begin{array}{l}\text { Methods allowing for the dynamic, historical } \\
\text { and cultural changes and genesis of institutions, } \\
\text { discovering rules and patterns, cultural/ } \\
\text { historical analysis, not only formal but non- } \\
\text { formal, plurality of empirical methods, not } \\
\text { confined to simple testable models }\end{array}$ \\
\hline $\begin{array}{l}\text { Evolutionary economics } \\
\text { Holon, heterogeneous, interdependent, } \\
\text { embedded in the social and natural } \\
\text { world, changing, with various needs, } \\
\text { altruistic and egoistic, cooperative } \\
\text { and competitive, bounded rationality }\end{array}$ & \multicolumn{1}{|c}{} \\
\hline
\end{tabular}

Source: own work.

\footnotetext{
${ }^{44}$ This issue was the subject of the so-called second Methodenstreit between the representatives of the historical school - Werner Sombart and Max Weber.
} 
The issues discussed above have an impact on the preferences for particular methods expressed by diverse economic schools (see Table 4).

Neoclassical economics, due to its vision of the world and Man (a deistic, dualistic vision containing homogeneous people with built-in preferences), favours mathematical models. Additionally, it prefers very formal methods that do not require more 'humanistic' methods due to the assumptions about the independence of human beings in their preferences. Therefore, the economic model of Man does not consider any historical or cultural influences but prefers physical, mathematical and formal models to explain the reality, which have to fulfil the condition of being testable.

On the contrary, evolutionary economics, because of the assumption of the constant changing of its objects, their interdependency and their cultural and historical setting, has a preference for cultural and historical analysis. It combines both formal and non-formal methods and applies a plurality of empirical methods. The methods, according to Eparvier (2005: 221), that dominate in evolutionary economics are verbal-economical, interpretations of statistical materials, mathematical-statistical definitions, historical statistics, historical analysis, historical literature overview, philosophical analysis and methodological analysis.

\section{(6)General features of the methodology}

\section{(approach to the question of methodological individualism)}

There is one further element of methodology that could perhaps be assigned to the epistemological issues: the way of explaining the complexity of the world.

Neoclassical economics applies here 'methodological individualism', which means that all phenomena are explained as if they were a consequence of individual decisions. It is believed that there is a free market, which harmonizes all the decisions taken by the individuals. Furthermore, it is assumed that the human being is an egoistic person who enters only into economic relations through the market, disregarding all interchange contacts even in the organization. ${ }^{45}$ Only the competitive character of the human being is of importance, and there is no place for group decisions and organizational decisions.

Evolutionary economics is critical about such an approach, because for it the phenomena are much too complex to explain them with a harmonizing force of the market. They are considered as an effect of individual decisions,

\footnotetext{
${ }^{45}$ Which, in reality, is not based only on competition but much more on cooperation.
} 
group, organizational and institutional decisions. Additionally, they include the time horizon, which means that today's decisions are a consequence of previous ones. The theory of the firm can be taken as an example.

\section{(7)Basic assumptions (axioms)}

The basic assumptions that form the centre of the basic methods and theories are part of the methodology as well. They have the character of axioms - assumptions taken without proof - that build the basis of a theory.

The axioms in neoclassical economics are treated as laws able to explain many phenomena. This is the result of the mechanistic, physical worldview, in which all phenomena are subordinated to some fixed laws. The neoclassical economic thought is built on the following three axioms (Söllner, 2001). The first assumption is about the optimization within constraints, which is considered as the fundament of neoclassical economics, ${ }^{46}$ requiring a marginal analysis. Only choices based on optimization are considered to be rational. The second assumption concerns the existence of equilibrium, which has two forms: (1) individual equilibrium, which is reached when individuals maximize their utility; and (2) market equilibrium, which refers to equilibrium in one market (partial equilibrium) or all markets (total equilibrium). Market equilibrium means that there is no motive anymore for individuals to change their behaviour. Both the optimization and the equilibrium assumption are part of the physical world. The third assumption concerns methodological individualism, which means that all economic phenomena can be and have to be explained by individual actions (Söllner, 2001).

Completely contrary methodological assumptions build the basis for evolutionary economics. This is because it focuses not on individuals but on groups and institutions and because it assumes that a person is a social being. Moreover, his/her motivation is not to maximize utility but to secure the passing on of the 'gene'. ${ }^{47}$ This 'gene' translated into evolutionary economics refers to knowledge. The major processes and interchanges in the economy can be explained in terms of sharing knowledge. It is assumed in the first place that knowledge production and distribution are the basis of all processes. Secondly, ideas and knowledge are articulated in the language of the social domain. We always have to communicate knowledge to others

\footnotetext{
${ }^{46}$ The optimization of a goal function, within some constraints, such as income, budget, factor and amount of production.

${ }^{47}$ Therefore some evolutionary economists prefer to speak about fitting and not about utility.
} 
within the social context. The following three axioms are considered as ontological axioms: (1) phenomena are carriers of knowledge and they evolve; (2) generic ideas are the elements of a process and build cognitive processes and shape behaviour; and (3) the causality has an evolutionalformative character. There are also three empirical axioms: (1) real phenomena are actualizations of ideas; (2) actualizations are matter-energy actualizations in time and space; and (3) real phenomena evolve (Eparvier, 2005).

\section{(8)Main unit of the research}

Likewise, the specification of the main unit of research which is also a task of methodology, seems to be influenced by the concept of human nature. Therefore it is no wonder that, according to the assumption of neoclassical economics, the basic/main unit of research is a homogeneous, independent, standardized individual or firm. The standardization allows for later aggregation of the results.

On the other hand, the evolutionary economics' changing and adapting vision of Man leads to a different basic research unit. Namely, it is an entity or humanity as a whole (not a mere aggregation) or even an adapting organization, a gene, or the knowledge ('a heritage'). The last element is a consequence of assuming that a human being or an organization is only a carrier of knowledge, like an organization.

A further difference lies in the approach to the kind of phenomena interesting to the researcher. These, according to Wagner (2011: 305), are not 'states' as in neoclassical economics (German: Zustand) but 'transition processes' (German: Übergangsprozesse).

\section{(9)Scientific approach (descriptive, positive or normative)}

A further methodological problem concerns the character of the whole particular science. Generally speaking, there are three basic approaches: descriptive, positive and normative. The choice of economics regarding its character stays in relation to and is conjoined with the question about the character of all social sciences. The second Methodenstreit, called Werturteilsstreit, ${ }^{48}$ is finalized in the acceptance of the free-of value - the positive character of the science. This causes an adaptation of Popper's suggestions regarding the way to develop theories and test them without making any normative statements. As a consequence, neoclassical thought

\footnotetext{
${ }^{48}$ The first 'Methodenstreit' was about the inductive/deductive character of the science.
} 
focuses on the positive explanation due to the assumption that the person's behaviour is subordinated to a particular rule of behaviour (utility maximization).

According to evolutionary economics a person cannot be reduced to such simplified rules, because his/her adapting behaviour follows rules that change, so we can speak more about structures and patterns. In order to discover them, evolutionary economics cannot construct positive models but has to value a pure description, which allow to discover rules which 'fit' better than others, dominant structures and patterns of adaptation. They can help to build some 'laws' which, differently to positive approach, are not oriented on forecasting, but rather allowing understanding.

\section{(10)Meta-methodological issues}

Last but not least, there are also some meta-methodological issues that provide an insight into the self-reflection of the science.

Neoclassical economics, due to its physical worldview level of the concept of human nature, believes in the universality of developed rules and their superiority to others. There is no place for pluralism and relativism, only for the belief that these rules or laws are true and any contrary ones are not. The goal of the science is to develop those laws and discover new ones that are congruent with them. The progress of science is considered as a logical progress.

The evolutionary, complex, biological concept of human nature exerts an impact on the attitude towards meta-economics. It is treated as the umbrella over diverse economic thoughts developed within different schools of economics. The idea that there is one core in economics, which is then developed successively, is abandoned. Evolutionary economics, therefore, according to Nishibe (2006: 12-13), develops meta-economics by integrating the history of economic thought into economics. Meta-economics means that the concepts and theories are perceived not as stable but as undergoing constant change. This has an impact on research programmes, the role of economics and the self-understanding of the discipline. In addition, there is no one unique answer to the phenomena described. Therefore, such an approach seeks the integration of theory and history to study different schools and doctrines synchronically as in the comparative history of economics. Nishibe (2006: 14) maintains that "the role of evolutionary economics as meta-economics is to make us keenly aware of the diversity of those eyes and to integrate images of two-dimensional planes cut-off by different approaches into a three-dimensional solid of reality". 
Further (p. 15): "The role of economics is therefore not only to objectively/mind-independently observe a socio-economy from outside and explain its structure and mechanism from an evolutionary perspective but also to become self-aware of its own 'social' status and power as a social practice within a socio-economy". Economists are not external observers of an economic system but internal observers/practitioners, who belong within the socio-economy and commit themselves to its constitution and evolution. $^{49}$ Therefore, such thinking results in methodological pluralism ${ }^{50}$ (Caldwell, 2001), with diverse sets of concepts, methods of study or proper domains which compete and coexist. It is assumed that there is no one right methodology which may be ascribed to the evolutionary, complex, biological concept of human nature.

\section{CONCLUSION}

There are profound differences between evolutionary economics and neoclassical economics in their views on methodological issues encompassing such groups of aspects as: basic metaphors and paradigms; ontological issues; epistemological problems; approach to interdisciplinarity; the way of reaching scientific statements; basic methods; attitude towards methodological individualism; basic assumptions (axioms); basic unit of research; dominant scientific approach: descriptive, positive or normative; and meta-economics.

The analysis reveals that each methodological difference between neoclassical and evolutionary economics can be seen as a result of various assumptions of these schools about human nature. A human nature is a complex system and can be characterized by diverse dimensions (worldview, social world and individual world) and levels (body, mind and soul). It is evolutionary economics that is close to such a view of human being, whereas neoclassical economics, focusing on utility maximization, individualism and competition, actually treats a human nature as a type of simple system. One of the consequences of this methodological simplification is the way of perceiving the environment and its role, as neoclassical economics sees it as stable and not playing an important role in decision making.

\footnotetext{
${ }^{49}$ See the discussion about the development of science as an effect of logical reasons within science itself or because of other out-of-science reasons.

${ }^{50}$ Bouwel (2005) identifies five distinct motivations for pluralism in economics: 1) ontological motivation; 2) cognitive limitations as a reason for plurality, 3) historical and geographical location as a source of pluralism; 4) pragmatic motivation and 5) strategic motivation (Nishibe, 2006: 15).
} 
Referring to the individual dimension of human nature, the methodological features of neoclassical economics such as the predominance of the positive approach, deductive-inductive way of reasoning, preference for mathematical modelling and objective methods can be considered as the consequence of assuming only one motive explaining human behaviour, namely utility maximization. In contrast, considering more motives or reflecting on other than the utility-calculating function of reason, as evolutionary economics does, requires the application of a new methodological approach, as for instance the preference for the descriptive approach, considering intersubjective and inductive methods.

Seeing the social world as based only on competition (neoclassical economics) or both on competition and on cooperation (evolutionary economic) results in diverse approaches to the question about methodological individualism and the analysis of the basic research unit, which prevails in neoclassical economics and is criticized in evolutionary economics.

Similarly, the use of physical (Newtonian) metaphors by neoclassical economics and rather biological ones by evolutionary economics can be explained by their diverse worldviews which translate into diverse perspectives on understanding humans in the world and society as autonomous or adapting to the given social and biological circumstances. This is also responsible for thinking about economic phenomena as objects (by neoclassical economics) and as processes (by evolutionary economics).

To sum up, the assumptions about human nature are crucial for both neoclassical economics and evolutionary economics because they influence the way of thinking about their methodology. However, we should conclude that evolutionary economics, assuming a more complex concept of human nature and representing multidisciplinary approach, is more able to explain real economic systems with their changes and challenges. Hence the economic science needs the further development of interdisciplinary anthropological research as its new insights can be the source of future fundamental changes within economics.

\section{REFERENCES}

Alchian, A. A., Uncertainty, Evolution, and Economic Theory, "Journal of Political Economy", 58, pp. 211-221, 1950.

Andersen, E. S., Holm, J. R., The Signs of Change in Economic Evolution, "Journal of Evolutionary Economics", 24, pp. 291-316, 2014. 
Aristotle, Everson, S., Aristotle, the Politics, Cambridge, Cambridge University Press, Cambridge, 1988.

Arrow, K. J., Viewpoint: The Future, “Science”, pp. 1617-1618, 1995.

Arthur, W. B., Complexity and the Economy. Oxford University Press, New York, 2015a.

Arthur, W. B., Complexity Economics: A Different Framework for Economic Thought, "Terra Economicus", 13, pp. 15-37, 2015b.

Aruka, Y., Mimkes, J., An Evolutionary Theory of Economic Interaction-Introduction to Socioand Econo-Physics, "Evolutionary and Institutional Economics Review", 2, pp. 145-160, 2005.

Aruka, Y., Mimkes, J., An Evolutionary Theory of Economic Interaction -Introduction to Socioand Econo-Physics, "Evolutionary and Institutional Economics Review", 2, pp. 145-160, 2006.

Backhouse, R. E., New Directions in Economic Methodology. Routledge, London, 1996.

Bartkowiak, R., Historia myśli ekonomicznej [The history of economic thought]. Państwowe Wydawnictwo Ekonomiczne, Warszawa, 2008.

Bartling, H., Luzius, F., Grundzüge der Volkswirtschaftslehre: Einführung in die Wirtschaftstheorie und Wirtschaftspolitik [Guidelines to Economics: Introduction to the Economic Theory and Economic Policy]. Vahlen, München, 2000.

Becker, G. S., Altruism, Egoism, and Genetic Fitness: Economics and Sociobiology, "Journal of Economic Literature", 14, pp. 817-826, 1976a.

Becker, G. S., The Economic Approach to Human Behavior [in:] Becker, G. S. (ed.) The Economics Approach to Human Behavior. University of Chicago Press, Chicago, 1976b.

Bentham, J., Mill, J. S., The Utilitarians. Anchor Press, Garden City, NY, 1973.

Blaug, M., The Methodology of Economics: Or How Economists Explain. Cambridge University Press, Cambridge, 1997.

Bouwel, J. V., Towards a Framework for Pluralism in Economics, "Post-Autistic Economics Review", 30, 2005.

Caldwell, B. J., Beyond Positivism: Economic Methodology in the Twentieth Century. Routledge, London, 2001.

Colander, D., The Death of Neoclassical Economics, "Journal of the History of Economic Thought", 22, pp. 127-143, 2000.

Colander, D., The Future of Economics: The Appropriately Educated in Pursuit of the Knowable, "Cambridge Journal of Economics", 29, pp. 927-941, 2005a.

Colander, D., The Making of an Economist Redux, "The Journal of Economic Perspectives", 19, pp. 175-198.

Colander, D., Holt, R., Rosser, B., The Changing Face of Mainstream Economics, "Review of Political Economy, Taylor and Francis Journals", 16, pp. 485-499, 2004.

Collins, J., Baer, B., Weber, E. J., The Evolutionary Foundations of Economics, University of Western Australia Economics Discussion Paper, 2015.

Cournot, A.-A., Recherches sur les principes mathématiques de la théorie des richesses [Researches into the Mathematical Principles of the Theory of Wealth]. Hachette, Paris, 1838 
Darwin, C., On the Origin of Species, London, John Murray, London, 1859.

Davis, J., Economics Imperialism versus Multidisciplinarity. "History of Economic Ideas" 24/3, pp. 77-84.

Davis, J. B., Economic Methodology since Kuhn [in:] Samuels, W. (ed.) A Companion to the History of Economic Thought. Wiley-Blackwell, Oxford, 2003.

Davis, J. B., The Turn in Economics: Neoclassical Dominance to Mainstream Pluralism? "Journal of Institutional Economics",2, pp. 1-20, 2006.

Dawkins, R., Jannasz, M., Rzeka genów [River Out of Eden: A Darwinian View of Life]. CIS, Warszawa, 1995.

Dawkins, R., In Defence of Selfish Genes, "Philosophy”, 56, pp. 556-573, 1981.

Dopfer, K. (ed.), Evolutionary Economics: Program and Scope. Kluwer Academic Publications, Boston, 2001.

Dopfer, K., Potts, J., Evolutionary Foundations of Economics [in:] Metcalfe, J. S., Foster, J. (eds.) Evolution and Economic Complexity. Edward Elgar, Cheltenham, 2004.

Dopfer, K., Potts, J., Evolutionary Realism: A New Ontology for Economics, "Journal of Economic Methodology", 11, pp. 195-212, 2010.

Dopfer, K., Foster, J., Potts, J., Micro-meso-macro, “Journal of Evolutionary Economics", 14, pp. 263-279, 2004.

Dupuit, J., On the Measurement of the Utility of Public Works, "International Economic Papers", 2, pp. 83-110, 1844.

Edgeworth, F. Y., Mathematical Psychics: An Essay on the Application of Mathematics to the Moral Sciences, London, Kegan Paul, London, 1881.

Ekelund, R. \& Hebert, R., A History of Economic Theory and Method. Mcgraw-Hill International Editions, New York, 1997.

Eparvier, P., Some Comments on the Methodological Principles of Nelson and Winter's Evolutionary Theory, "Evolutionary and Institutional Economics Review", 1, 221-234, 2005.

Fahrenberg, J., Menschenbilder [Concepts of Human Nature] [in:] Wirtz, M. A. (ed.), Dorsch - Lexikon der Psychologie [Dorsch-Dictionary of Psychology]. Verlag Hans Huber, Bern, 2014.

Fisher, I., Mathematical Investigations in the Theory of Value and Prices, "Transactions of the Connecticut Academy of Arts and Sciences", 9, pp. 1-124, 1892.

Fontana, M., Can Neoclassical Economics Handle Complexity? The Fallacy of the Oil Spot Dynamic, "Journal of Economics Behavior \& Organization”, 76, pp. 584-596, 2010.

Frankl, V. E., Man's Search for Meaning. Pocket Books, 1997.

Georgescu-Roegen, N., The Entropy Law and the Economic Process. Harvard University Press, Cambridge, 1971.

Gossen, H. H., Entwicklung der Gesetze des menschlichen Verkehrsund der daraus fließenden Regeln für menschliches Handeln [The Laws of Human Relations and the Rules of Human Action Derived Therefrom]. Prager, Berlin, 1854.

Granberg, A. G., Modellierung der sozialistischen Wirtschaft. Theoretische und methodologische Probleme [Modeling the Socialist Economy. Theoretical and Methodological Problems]. Akademie-Verlag, Berlin, 1981. 
Haken, H., Synergetics. An Introduction. Nonequilibrium Phase Transitions and Self-Organization in Physics, Chemistry and Biology. Spinger-Verlag, Berlin/Heidelberg, 1977.

Hardt, Ł., Studia z realistycznej filozofii ekonomii [Research about Realistic Philosophy of Economics]. C. H. Beck, Warszawa, 2013.

Hausman, D. M., A New Era for Economic Methodology, "Journal of Economic Methodology”, 8, pp. 65-68, 2001.

Hayek, F. A., The Use of Knowledge in Society, "The American Economic Review", 35, pp. 519-530, 1945.

Hayek, F. A., Recht, Gesetzgebung und Freiheit Bd. 1: Regeln und Ordnung: eine neue Darstellung der liberalen Prinzipien der Gerechtigkeit und der politischen Ökonomie [Law, Legislation and Freedom Volume 1: Rules and Order: A New Presentation of the Liberal Principles of Justice and Political Economy]. Verlag Moderne Industrie, München, 1980.

Herrmann-Pillath, C., Social Capital and Networks: A Proposal for Conceptual Integration. Witten Universität, Witten, 2000.

Hirshleifer, J., Economics from a Biological Viewpoint, "Journal of Law and Economics", 20, pp. 1-50, 1977.

Hirshleifer, J., Natural Economy versus Political Economy, "Journal of Social and Biological Structures", 1, pp. 319-337, 1978.

Hobbes, T., Macpherson, C. B., Leviathan. Penguin Books, Harmondsworth, 1987.

Hodgson, G. M., Economics and Evolution: Bringing Life Back into Economics, Cambridge and University of Michigan Press, Polity Press, 1993.

Hodgson, G. M., Economics and Utopia: Why the Learning Economy is Not the End of History. Routledge, London, 1999a.

Hodgson, G. M., Evolution and Institutions: On Evolutionary Economics and the Evolution of Institutions. Edward Elgar, Cheltenham, 1999b.

Hodgson, G. M., How Economics Forgot History. Routledge, London, 2001.

Hodgson, G. M., Characterizing Institutional and Heterodox Economics - A Reply to Tony Lawson, "Evolutionary and Institutional Economics Review", 2, pp. 213-223, 2005.

Hodgson, G. M., Evolutionary and Institutional Economics as the New Mainstream? "Evolutionary and Institutional Economics Review", 4, pp. 7-25, 2007.

Hodgson, G. M., Toward an Evolutionary and Moral Science Remarks upon Receipt of the Veblen-Commons Award, "Journal of Economic Issues", 48, pp. 265-275, 2012.

Hodgson, G. M., From Pleasure Machines to Moral Communities. An Evolutionary Economics without Homo Economicus. University of Chicago Press, Chicago, 2013.

Holub, H. W., Der Konfliktansatz als Alternative zur makroökonomischen Gleichgewichtstheorie [The Conflict Approach as an Alternative to Macroeconomic Equilibrium Theory]. Holleis, Göttingen, 1978.

Horodecka, A., Wptyw filozofii życia na ekonomie [The Impact of Philosophy of Life on the Economy]. Kwartalnik Nauk o Przedsiębiorstwie 19, pp. 41-47, $2011 \mathrm{a}$.

Horodecka, A., Wplyw filozofii, w tym filozofii nauk na zmiany $w$ metodologii ekonomicznej $i$ teorii ekonomicznej [The Influence of Philosophy Especially Philosophy of Science on the Changes in Economic Methodology and on Theory of Economics], "Zeszyty Naukowe 
Uniwersytetu Ekonomicznego w Poznaniu" [Research of the University of Economics in Poznań] 190, pp. 68-90, 2011b.

Horodecka, A., Ekonomia na rozdrożu: pomiędzy monizmem i pluralizmem metodologicznym [Economics at the Crossroads: Between Methodological Monism and Pluralism] [in:] Stacewicz, J. (ed.) Polityka gospodarcza w poszukiwaniu nowego paradygmatu [Economic Policy in Search of a New Paradigm]. Oficyna Wydawnicza SGH, Warszawa, 2013.

Horodecka, A., Homo oeconomicus jako podstawa ekonomii - krytyka $i$ alternatywy [Homo Oeconomicus as the Basis of Economics - Criticism and Alternatives]. "Prace Naukowe Uniwersytetu Ekonomicznego we Wrocławiu" [Research of the University of Economics in Wroclaw], 347, pp. 166-183, 2014a.

Horodecka, A. Komponenty obrazu czlowieka w ekonomii [Components of Concepts of Human Nature in the Economics], "Kwartalnik Historii Myśli Ekonomicznej”, 5, pp. 117-139, 2014b.

Horodecka, A., The Field of Evolutionary and Neoclassical Economics as a Consequence of the Changes in Concepts of Human Nature, "Journal of International Studies",8, pp. 126$-137,2015 \mathrm{a}$.

Horodecka, A., Reasons for Changes of the Concepts of Human Nature in Economics Exemplified on Contemporary Trends in Economics [in:] Balcerzak, A. P. (ed.) Proceedings of the 8th International Conference on Applied Economics. Contemporary Issues in Economy Market or Government?. Institute of Economic Research and Polish Economic Society Branch, Toruń, 2015b.

Hume, D., A Treatise of Human Nature: Being an Attempt to Introduce the Experimental Method of Reasoning into Moral Subjects. Clarendon Press, Oxford, 2007.

Jensen, H. E., The Theory of Human Nature, "Journal of Economic Issues", 21, pp. 1039$-1073,1987$.

Jevons, W. S., The Theory of Political Economy. Macmillan, London, 1888.

Kamiński, S., Z metafilozofi człowieka [Human Metaphilosophy] [in:] Krąpiec, M. A., (ed.) Ja-człowiek [I-Man]. KUL, 2005.

Kaneko, M., Kodama, T., Anti-System Science. Iwanami-shoten, Tokyo, 2004.

Kenrick, D. T., Griskevicius, V., Sundie, J. M., Li, N. P., Li, Y. J., Neuberg, S. L., Deep Rationality: The Evolutionary Economics of Decision Making, "Social Cognition", 27, p. 764, 2009.

Klimczak, B., Wizerunek współczesnego człowieka gospodarującego [Image of Contemporary Managing Man]. Wydawnictwo AE, Kraków, 2000.

Krąpiec, M. A., Ja-czlowiek [I-Man]. Wydawnictwo KUL, Lublin, 2005.

Kwaśnicki, W., Knowledge, Innovation and Economy: An Evolutionary Exploration. Edward Elgar Publishing, Cheltenham, 1996.

Lawson, T., Economics and Reality. Routledge, London, 1997.

Lawson, T., Modern Economics: The Problem and a Solution. A Guide to What's Wrong with Economics. Anthem Press, London, 2004.

Lee, F. S., A History of Heterodox Economics. Changing the Mainstream in the Twentieth Century. Routledge, London, 2009.

Lehmann-Waffenschmidt, M., Economic Evolution, a General Equilibrium Analysis, Heidelberg, Springer, 1990. 
Lennox, J., Darwinism [in:] Zalta, E. N. (ed.) The Stanford Encyclopedia of Philosophy, 2010.

Luhmann, N., Soziale Systeme: Grundriß einer allgemeinen Theorie [Social Systems]. Suhrkamp, Frankfurt am Main, 1994.

Mäki, U., Studies in Realism and Explanation in Economics. Suomalainen, Helsinki, 1990.

Mäki, U., Fact and Fiction in Economics: Models, Realism, and Social Construction. Cambridge University Press, Cambridge, 2002.

Mäki, U., Realism and Economic Methodology. Routledge, London, 2006.

Marshall, A., The Principles of Economics. Macmillan, 1920.

Marx, K., Capital. Penguin, New York, 1990.

Mccloskey, D. N., The Rhetoric of Economics. Wheatsheaf, Brighton, 1986.

Mirowski, P., More Heat than Light: Economics as Social Physics: Physics as Nature's Economics. Cambridge University Press, Cambridge, 1999.

Nelson, R. R., Winter, S. G., Neoclassical vs. Evolutionary Theories of Economic Growth: Critique and Prospectus, "The Economic Journal”, pp. 886-905, 1974.

Nelson, R. R., Winter, S. G., An Evolutionary Theory of Economic Change. Belknap Press of Harvard University Press, Cambridge Mass., 1982.

Nelson, R. R., Winter, S. G., Evolutionary Theorizing in Economics, "Journal of Economic Perspectives", 16, pp. 23-46, 2002.

Nishibe, M., Redefining Evolutionary Economics, "Evolutionary and Institutional Economics Review", 3, pp. 3-25, 2006.

Nussbaum, M. C., Capabilities as Fundamental Entitlements: Sen and Social Justice. Feminist Economics, 9, pp. 33-59, 2003.

Platon, Regner, L., Faidros. PWN, Warszawa, 2004.

Poirot, C., Is Pragmatism Good for Anything? Towards a Theory of Impractical Economics. Forum for Social Economics, 37, pp. 61-76, 2008.

Popper, K. R., Logik der Forschung [The Logic of Scientific Discovery]. Mohr Siebeck, Tübingen, 2002.

Rembold, S., Das Bild des Menschen als Grundlage der Ordnung. Die Beiträge von Platon, Aristoteles, Thomas Hobbes, John Locke, David Hume, Adam Smith, John Stuart Mill, Walter Eucken und Friedrich August von Hayek [The Concept of Human Nature as the Basis of Order. The contributions of Plato, Aristotle, Thomas Hobbes, John Locke, David Hume, Adam Smith, John Stuart Mill, Walter Eucken and Friedrich August von Hayek]. Universität zu Köln, 2006.

Ricardo, D., On the Principles of Political Economy and Taxation [in:] Sraffa, P. (ed.) The Works and Correspondence of David Ricardo. Cambridge University Press, Cambridge, 1815.

Rolle, R. U., Homo oeconomicus: Wirtschaftsanthropologie in philosophischer Perspektive [Homo Oeconomicus: Economic Anthropology in a Philosophical Perspective]. Königshausen \& Neumann, Würzburg, 2005.

Rubin, P. H., Paul, C. W., An Evolutionary Model of Taste for Risk, "Economic Inquiry", 17, pp. 585-596, 1979.

Samuels, W. J., Biddle, J. E., Davis, J. B. (eds.), A Companion to the History of Economic Thought. Blackwell, Malden, Mass., 2003.

Say, J.-B., A Treatise on Political Economy. John Grigg, Philadelphia, 1803. 
Schopenhauer, Die Welt als Wille und Vorstellung [The World as Will and Representation]. F. A. Brockhaus, Lepizig, 1819.

Schumpeter, J. A., Theorie der wirtschaftlichen Entwicklung [The Theory of Economic Development]. Duncker \& Humblot, Leipzig, 1911.

Schumpeter, J. A., History of Economic Analysis. Oxford University Press, New York, 1954.

Sen, A., Development as Freedom. Knopf, New York, 1999.

Simon, H., Models of Man: Social and Rational; Mathematical Essays on Rational Human Behavior in Society Setting. Wiley, New York, 1957a.

Simon, H. A., Models of Man: Social and Rational; Mathematical Essays on Rational Human Behavior in Society Setting, New York, Wiley, New York, 1957b.

Smith, A., An Inquiry into the Nature and Causes of the Wealth of Nations. University of Chicago Press, Chicago, 2005.

Söllner, F., Die Geschichte des ökonomischen Denkens [The History of Economic Thinking]. Springer, Berlin, 2001.

Steup, M., Epistemology [in:] Zalta, E. N. (ed.) The Stanford Encyclopedia of Philosophy, $U R L=<$ https://plato.stanford.edu/archives/fall2017/entries/epistemology/>. 2017.

Szarzec, K., Koncepcje racjonalności działania gospodarczego $w$ teorii ekonomii [Concepts of Economic Rationality in Economic Theory], "Ruch Prawniczy, Ekonomiczny i Socjologiczny" 64, pp. 155-169, 2002.

Taylor, E., Wstęp do ekonomiki [Introduction to Economics]. Wydawnictwo Poznanskiego Towarzystwa Przyjaciól Nauk, 2004.

Thies, C., Einführung in die philosophische Anthropologie [Introduction to Philosophical Anthropology]. Wissenschaftliche Buchgesellschaft, Darmstadt, 2004.

Veblen, T., Why is Economics Not an Evolutionary Science?, "The Quarterly Journal of Economics", 12, pp. 373-397, 1898.

Veblen, T., The Theory of the Leisure Class. Penguin Books, New York, 1967.

Vilfredo, P., Manuale di economia politica [Handbook of Political Economics]. Società editrice libraría, Milan. Revised and translated into French as Manuel d'économie politique. Giard \& Brière, Paris, 1909.

Von Thünen, J. H., Der isolierte Staat in Beziehung auf Nationalökonomie und Landwirtschaft [The Isolated State in Relation to National Economy and Agriculture]. Gustav Fischer, Stuttgart, 1826.

Wagner, A., Fortgeschrittene Evolutorische Ökonomik [Advanced Evolutionary Economics], "Jahrbücher für Nationalökonomie und Statistik" pp. 304-313, 2011.

Walras, L., Elements of Pure Economics. Routledge, London, 2013.

Wilson, D. S., Gowdy, J. M., Rosser Jr., J. B. 2013. Rethinking Economics from an Evolutionary Perspective, "Journal of Economic Behavior \& Organization", 90, S1-S2.

Zboroń, H., Teorie ekonomiczne w perspektywie poznawczej konstruktywizmu społecznego [Economic Theories in the Cognitive Perspective of Social Constructivism]. Wydawnictwo Uniwersytetu Ekonomicznego w Poznaniu, Poznań, 2009.

Received: November 2015, revised: December 2016 